\title{
Follow-up in Head and Neck Cancer: Do More Does It Mean Do Better? A Systematic Review and Our Proposal Based on Our Experience
}

\author{
Nerina Denaro ${ }^{1}$ Marco Carlo Merlano ${ }^{1}$ Elvio Grazioso Russi ${ }^{2}$ \\ Departments of ${ }^{1}$ Oncology and ${ }^{2}$ Radiation Oncology, A.S.O. Santa Croce e Carle, Cuneo, Italy
}

As the patients population ages, cancer screening increases, and cancer treatments improve, millions more head and neck carcinoma (HNC) patients will be classified as cancer survivors in the future. Change in epidemiology with human papillomavirus related HNC leads to a number of young treated patients. After treatment for HNC intensive surveillance, including ear, nose and throat (ENT) endoscopy, imaging, and serology, confers a survival benefit that became less evident in unresectable recurrence. We performed a comprehensive revision of literature and analyzed the experience of our centre. We revised publications on this topic and added data derived from the interdisciplinary work of experts within medical oncology, ENT, and radiation oncology scientific societies. We retrospectively collected local and distant recurrence of chemoradiation treated patients at Santa Croce and Carle University Hospital. A HNC follow-up program is not already codified and worldwide accepted. There is a need of scheduled follow-up. We suggest adopting a standardized follow-up guideline, although a multidisciplinary approach is frequently requested to tailor surveillance program and treatment on each patient.

Keywords. Head and Neck Neoplasms; Imaging; Surveillance; Human Papillomavirus; Second Primary Tumor

\section{INTRODUCTION}

Head and neck carcinoma (HNC) is the sixth most common cancer worldwide. Approximately two thirds of HNC patients (HNCPs) presents with locally advanced disease (LA-HNC). The curative rate for early stage disease is high. On the contrary despite technological advances in radiotherapy (RT) techniques, the development of bio-RT and new chemotherapy-RT combinations, about $40 \%$ of LA-HNC will not respond or recur after front line treatment. Fifty percent to $60 \%$ of these patients develop a loco-regional recurrence within 2 years. In addition, $20 \%$ to $30 \%$ of those patients develop distant metastases. Second primary risk is about $2 \%$ to $4 \%$ per year, a rate of about $10 \%$ to $20 \%$ overall lifetime risk $[1,2]$.

However the overall prevalence of patients living with a diag-

\footnotetext{
- Received June 12, 2015

Revised December 2, 2015

Accepted December 29, 2015

- Corresponding author: Nerina Denaro

Department of Oncology,A.S.O. Santa Croce e Carle, 12100, Cuneo, Italy Tel: +39-3202216583, Fax: +39-0171616360

E-mail: nerinadenaro@gmail.com
}

nosis of $\mathrm{HNC}$ is increasing in the industrialized countries, thus management of HNC survivors represents a daily practice problem for both oncologists and primary care physicians.

In general, the proper assessment of any cancer surveillance program must consider (1) the recurrence rate, (2) the optimal method for surveillance, and (3) whether earlier detection of recurrence leads to increased rates of successful salvage treatment and improved survival. Follow-up in HNC patients has several goals: to assess clinical response and late effects of treatment; to detect recurrences and second cancers at an early stage; and to restore nutritional and psychosocial status [3].

Therefore in HNC patients, follow-up is proposed not only to assess therapy consequences and to prescribe rehabilitation of functional loss and pain management but also for a curative intent (timely identification of locoregional recurrence or metastasis and second tumors).

Follow-up visit should include physical examination of cranial nerve examination, an assessment of vocal, breathing and swallowing functions, and a systemic pain evaluation using a visual analogic scale [4].

After basal imaging reimaging should be prescribed in symptomatic patient or in those for which a super-intensive follow-up

Copyright @ 2016 by Korean Society of Otorhinolaryngology-Head and Neck Surgery.

This is an open-access article distributed under the terms of the Creative Commons Attribution Non-Commercial License (http://creativecommons.org/licenses/by-nc/4.0)

which permits unrestricted non-commercial use, distribution, and reproduction in any medium, provided the original work is properly cited. 
is suggested. Chest computed tomography (CT) scan is needed if a chest imaging is requested. Hermans et al. [5] demonstrated that only $33 \%$ of intra-thoracic lesions picked up by chest CT were also detected by chest $\mathrm{X}$-ray.

Oligometastatic disease might be curable and salvage rates depend on several factors including human papillomavirus (HPV) status, site, and number of metastases. Surgical salvage after failure of chemoradiation (CRT) is feasible. Patients that may benefit from surgery include those without regional recurrence and/or those in whom negative margins can be obtained. However, patients treated with salvage surgery may be tracheotomy or gastrostomy tube dependent. p16 status did not appear to have prognostic impact in the salvage setting [6].

The overall survival (OS) rate of patients treated with re-irradiation at 2-year range from $30 \%$ to $67 \%$ according to RT techniques (external beam 3-dimensional RT versus intensity modulated RT versus high-dose-rate brachytherapy) and disease extension (outcome in resectable disease suitable for re-irradiation ranges from $30 \%$ to $48 \%$ while outcome with re-irradiation in non-resectable disease ranges from $5 \%$ to $20 \%$ at 2 years) [6-10].

Follow-up protocols should avoid unnecessary investigations that may cause morbidity or discomfort to the patient and may have significant cost implications without impact on survival. The follow-up surveillance for pts who have received definitive treatment for HNC as well as those being treated for LA-HNC is discussed in this paper. HNC represent a heterogeneous group of cancers: a rigid one-size-fits-all approach of follow-up is questionable, and there is currently an ongoing professional debate to determine the optimum duration and content of follow-up care.

The aims of this paper are (1) to discuss current state of art and differences on surveillance programs and (2) to hint a flow chart for each subsites.

\section{MATERIALS AND METHODS}

A comprehensive literature review was finalized in April 2015. The Medline were searched with the date parameters of January 1981 through April 2015. The decision of this range was made on the basis of publication date of the most important research

\section{H I}

- Follow-up in head and neck carcinoma patients after curative chemoradiation remains a controversial issue.

- The management and rehabilitation of treatment side effects are essential during follow-up.

- We suggest a different follow-up strategy based on prognosis (possibility of curability), comorbidities, and choice of patients.

- A cost effectiveness balance is necessary to avoid under- or overtreatment. clinical trials.

Electronic search results were supplemented with hand searching of selected reviews, expert consensus meeting notes, and reference lists from selected articles. The literature search was limited to articles in English and human patients. The following MeSH (Medical Subject Headings) terms and keywords were used in the search: head and neck cancer, recurrence, salvage surgery, surveillance, re-irradiation, and follow-up. We analysed and discussed the literature, taken into account the previous reported reviews on this matter.

\section{FOLLOW-UP PROBLEMS}

Based on our literature revision 3 major problems were highlighted: firstly, the lack of consolidated data about follow-up schedules (procedures+timing) among different institutions; secondly, the need of a tailored approach that consider also molecular prognostic factors and patient performance status/age; and finally, the lack of adequate evaluation of early and late side effects. The crucial unsolved question is whether a diagnosis of early recurrence in asymptomatic patient impact on quantity and quality of life.

\section{Heterogeneity follow-up schedules (procedures/timing)}

Routine surveillance has been associated with a survival benefit in some observational studies when patients diagnosed at routine follow-up were compared with those who presented with symptoms [11,12]. However, other studies have not observed a survival benefit from detecting asymptomatic recurrences [1316]. One explanation for the lack of a survival benefit may be the high proportion of recurrences that are symptomatic. Most recurrence are reported by the patient [17]. Other studies suggest that survival in patients with recurrent disease is determined primarily by the extent of prior disease and its therapy, time to recurrence, and the location of the recurrence [18].

Lack of survival benefit concordance among several reports depends mainly on patient populations: in early stage the time in which curable approach is still possible is longer than in late stage [11].

Cooney and Poulsen [19] in a study on 302 patients observed 119 recurrences with only 2 cured. The authors concluded that routine follow-up is more important for treatment evaluation and patients' reassurance than for true benefit in improving patients' survival. In contrast Hermans et al. [5] demonstrated the utility of reimaging with recurrence detections' anticipation and higher curable rates.

The role of chest $\mathrm{CT}$ is also much debated. On the one hand Hsu et al. [20] suggested 6-monthly chest CT for the first two years in order to detect early curable recurrence or second primary; on the other hand Ritoe et al. [12] failed to show an improvement in OS with a screening for second lung cancer after 
laryngeal cancer. Positron emission tomography (PET)/CT after CRT (post-treatment 12-week period) offer notable benefits. PET was significantly more sensitive than regular follow-up for identification of recurrence in several prospective and retrospective analyses [21-24]. Ho et al. [25] studied the impact of PET/ CT surveillance for detecting head and neck cancer recurrence at 12 and 24 months post-treatment. In a 10-year retrospective analysis of 284 patients the PET/CT detection rate of occult recurrence was $9 \%$ at 12 months and $4 \%$ during the second year, without 3-year disease free survival and OS difference compared to a larger group of patients who did not receive annually PET/ CT. Similarly, Dunsky et al. [26] confirmed a role of PET/CT for early detection of asymptomatic disease but the outcomes of those patients with identified recurrences remained poor.

Although the above mentioned agreement on the usefulness of imagine techniques for recurrence detections, no consensus has been reached so far regarding the most effective and efficient strategy [3]. Second primary malignancies (SPM) are common in HNCPs and have a negative impact on their survival [27]. Several reports confirm an average risk of $2 \%-4 \%$ per year, although their curability is higher compared with that of single lung metastases (35\% vs. $6 \%$ ) [27-29]. The most common sites of SPM are lung and superior aero-digestive tract $(60 \%$ vs. $20 \%$ ). Risk of SPM is due to common carcinogenesis and infield cancerization (mostly for HPV-negative tumors), therefore it can be reduced by elimination or reduction of exposure to carcinogens. A consultation and support from specialists in management of dependence should be advised [30-32].

A retrospective cohort study on 937 patients reported a cumulative incidence of SPMs at 6 months, 5 years, and 10 years after tumor diagnosis of $7.2 \%, 17.9 \%$, and $23.1 \%$, respectively. In the multivariate analyses, old age ( $>60$ years, $P=0.002$ ), hypopharyngeal index tumor site $(P=0.001)$, and heavy drinker $(P=0.001)$ were independently associated with the development of SPMs, and hypopharyngeal index tumor site were independent variables for SPM-specific survival $(P<0.001)$ [27]. The risk of synchronous SPMs has dramatically drop out in the last years as many oropharynx cancer are HPV related and there- fore there is few field cancerization. A large population-based cohort study in 64,673 patients in the National Cancer Institute Surveillance, Epidemiology, and End Results registry (19792008), defining the risks of synchronous SPM in HNCPs who were diagnosed before and after the emergence of prevalent HPV-associated oropharyngeal head and neck squamous cell carcinoma (HNSCC), confirmed this effect. The etiologic shift of oropharyngeal HNSCC require to investigate more for distant metastases than for synchronous SPMs in this population [33].

When feasible, salvage surgery is the treatment of choice both for recurrence and second primaries: with studies indicating a 5 -year survival rate of $35 \%$ in early locally recurrent tumors, $16 \%$ in advanced locally recurrent disease and $35 \%$ in radically resected second primary $[29,34,35]$.

Wong et al. [35] reported a site specific surgical salvage rates of recurrences: $29 \%$ for local, $30 \%$ for tracheostomal, $56 \%$ for unilateral nodal recurrence of previously undissected neck, $32 \%$ for unilateral neck recurrence after prior neck dissection, and 11\% for lung metastasis. The 5-year tumor-free actuarial survival rates on 337 patients were $35 \%$ for local recurrence, $32 \%$ for unilateral nodal recurrence of the previously undissected neck, and $18 \%$ for nodal recurrence of the previously dissected neck [35].

Follow-up strategies worldwide differ in the recommended frequency of office visits and number of interventions and imaging modalities. There is no evidence to suggest that any followup strategy is more efficient in detecting recurrences or improving the quality of life. National Comprehensive Cancer Network (NCCN) recommended from 7 to 27 office visits, post treatment baseline imaging within 6 months of treatment, and further imaging as indicated based on signs and symptoms in the 5 years after treatment. Chest X-ray or CT is recommended according to smoking history. A survey conducted among members of the American Society of Head and Neck Surgeons reported 73\% agreement among respondents for offering monthly follow-up in the first year after surgery, 2-3 monthly visits for the second year, and 4-6 monthly visits in years 3-5 after surgery [36,37]. Table 1 reports sensitivity and specificity of imaging techniques used in treatment evaluation and follow-up [22,38-41]. Table 2

Table 1. Radiologic imaging

\begin{tabular}{|c|c|c|c|c|c|c|}
\hline Exam & Study & $\begin{array}{c}\text { Sensitivity } \\
(\%)\end{array}$ & $\begin{array}{l}\text { Specificity } \\
(\%)\end{array}$ & $\begin{array}{r}\text { PPV } \\
(\%)\end{array}$ & $\begin{array}{r}\text { NPV } \\
(\%)\end{array}$ & Advantage \& disadvantage \\
\hline Ultrasound & $\begin{array}{l}\text { Hwang et al. (2009) [38] } \\
\text { Wierzbicka et al. (2011) [39] }\end{array}$ & 96.8 & 93.3 & 96 & 93 & $\begin{array}{l}\text { PPV and NPV, limited no. of } \\
\text { practitioners who are skilled in } \\
\text { HN ultrasonography }\end{array}$ \\
\hline MRI & Kangelaris et al. (2010) [40] & 50.0 & 83.0 & 25 & 94 & $\begin{array}{l}\text { Good anatomic delineation, low } \\
\text { sensitivity and specificity }\end{array}$ \\
\hline Diffusion weighted-MRI & Vandecaveye et al. (2012) [41] & 94.6 & 95.9 & $\begin{array}{l}89 \text { for } \mathrm{T} \\
70 \text { for } \mathrm{N}\end{array}$ & $\begin{array}{l}100 \text { for } \mathrm{T}, \\
96 \text { for } \mathrm{N}\end{array}$ & Higher accuracy, low diffusion \\
\hline $\begin{array}{l}\text { Positron emission tomography- } \\
\text { compute tomography }\end{array}$ & Kao et al. (2009) [22] & 92.0 & 82.0 & 42 & 98 & NPV, low PPV \\
\hline
\end{tabular}

PPV, positive predictive value; NPV, negative predictive value; MRI, magnetic resonance imaging; HN, head and neck; T, tumor; N, node. 
Table 2. Medical societies recommendations for clinical and endoscopic evaluation

\begin{tabular}{lcrrrrrr}
\hline Year (yr) & ASHNS [42] & BAHNO [43] & NCCN [37] & FSO [44] & DHNS [45] & AIRO [46] & AlOM [47] \\
\hline 1 & $1-3 \mathrm{mo}$ & $1-2 \mathrm{mo}$ & $1-3 \mathrm{mo}$ & $2 \mathrm{mo}$ & $2 \mathrm{mo}$ & $1-3 \mathrm{mo}$ & $3 \mathrm{mo}$ \\
2 & $2-4 \mathrm{mo}$ & $1-2 \mathrm{mo}$ & $2-4 \mathrm{mo}$ & $3 \mathrm{mo}$ & $3 \mathrm{mo}$ & $3 \mathrm{mo}$ & $3 \mathrm{mo}$ \\
3 & $3-6 \mathrm{mo}$ & $3 \mathrm{mo}$ & $4-6 \mathrm{mo}$ & $4 \mathrm{mo}$ & $4 \mathrm{mo}$ & $3 \mathrm{mo}$ & $3-6 \mathrm{mo}$ \\
4 & $4-6 \mathrm{mo}$ & $6 \mathrm{mo}$ & $4-6 \mathrm{mo}$ & $6 \mathrm{mo}$ & $6 \mathrm{mo}$ & $6 \mathrm{mo}$ & $6 \mathrm{mo}$ \\
5 & $4-6 \mathrm{mo}$ & $6 \mathrm{mo}$ & $4-6 \mathrm{mo}$ & $6 \mathrm{mo}$ & $6 \mathrm{mo}$ & $6 \mathrm{mo}$ & $6 \mathrm{mo}$ \\
$>5$ & $12 \mathrm{mo}$ & $12 \mathrm{mo}$ & $6-12 \mathrm{mo}$ & $12 \mathrm{mo}$ & Stop & $12 \mathrm{mo}$ & $12 \mathrm{mo}$ \\
\hline
\end{tabular}

ASHNS, American Society for Head and Neck Surgeon; BAHNO, British Association of Head and Neck Oncologists; NCCN, National Comprehensive Cancer Network; FSO, French ORL Society; DHNS, Dutch Head Neck Society; AIRO, Associazione Italiana Oncologia Medica; AIOM, Associazione Italiana Radioterapia Oncologica.

reports guidelines about follow-up of the most important scientific societies [37,42-47].

Lester and Wight [13] reported that for hypopharynx oropharynx and larynx $2.3,2.7$, and 4.7 years is the time in which 95\% of local recurrence occurs, moreover de Vischeer and Manni [11] confirmed curable episodes still possible only within 2 years for sub-glottic cancer and within 5 years for pharynx and oral cavity. For supra-glottic and early glottic cancer within 7 and 10 years curable episodes were registered.

Table 3 summarizes some of the most relevant studies on follow-up schedules [11-15,17-19,22,29,31,35,48-56].

\section{Need for a tailored approach}

Risk factors for recurrence include age, site of primary, sex, smoking status, and HPV status [57]. Moreover some prognosticators are also predictive factors: for example elderly patients are less likely to respond to CRT and are usually not fit for reirradiation or salvage surgery.

Elderly patients more often die of other causes than HNC and treatment side effects can seriously affect quality of life. However under-treatment is the extreme position mirroring over treatment and can negatively affect outcome. We have recently demonstrated that not age but comorbidity affect clinical outcome [58]. Important differences exist in the clinical behaviour (response, pattern, and timing of recurrences/metastases) between HPV positive and HPV negative HNSCC (mainly HPV positive oropharynx tumor).

Patients with HPV positive have a low recurrence risk [59]; therefore a less intense follow-up strategies may be hypothesized (at least for distant metastases) [60]. However, our understanding of the natural history of local and distant metastases in HPV positive tumors and its implications for surveillance is limited. Recently Trosman et al. [31] reported $1.11 \%$ and $23 \%$ rate of distant metastases in HPV positive and negative oropharynx tumor, with a longer median time to develop distant metastases for HPV disease (16.4 vs. 7.2 months; $P<0.008)$ but also with more metastatic sites (also atypical for HNC) than HPV negative tumors. The rate of 3-year OS was higher in the HPV+ group (89.9\% vs. $62.0 \%, P<0.001)$, as was the median survival after the occurrence of distant metastases regardless of addi- tional treatment (25.6 vs. 11.1 months, $P<0.001$ ) [31].

Pattern of failure may be different too: HPV positive tumors have lower locoregional recurrence than HPV negative ones but distant recurrence are similar. No variations were noted about acute and late toxicities [61].

Subramaniam et al. [62] suggest a role for fluorodeoxyglucose PET/CT in monitoring HPV positive HNCPs candidate to de-intensified treatments. The better prognosis and outcome of HPV positive oropharynx patients would warrant imaging follow-up that is less intense but continues longer because of the manifestation of distant metastases later in the disease course and at unusual sites [62].

Therefore it may be hypothesized that HPV positive may deserve a longer follow-up with body reimaging for atypical subsites and a less intensive ear, nose and throat (ENT) evaluation. Moreover a super-intensive imaging follow-up appear cost effective because in this population recurrences/metastases affect outcome less negatively than in HPV negative disease [3137,57-61]. However up to date there is no data to differentiate the surveillance plan of patients with HPV positive disease.

A tailored surveillance approach is desiderable not only for age and HPV status but also for other patient and tumor characteristic. In a large Canadian population-based study on 1,657 patients (diagnosed between 1986 and 1990) OS and HNC-specific mortality were statistically inferior among men, older age at diagnosis, advanced stages of disease, and oropharynx and hypopharynx primary cancer $(P<0.001)$ [63].

Site specific follow-up has been proposed by oncological, surgical, and radiation oncology societies. For oropharynx, hypopharynx, and larynx the schedule is super imposable 1-3 months for the first year; 3-4 months for the second and the third year, 6 months for the fourth and the fifth year, and then annually. For oral cavity the schedule is more intensive as well as for high risk tumors in which there is still a curative window. For unknown primary a super intensive follow-up is requested.

However in our opinion a critical revision of each patient is required if the patient is still eligible for curative intent a super intensive follow-up is justifiable.

In summary in a risk-stratification guided surveillance survival expectance should guide the choice more than the primary site 
Table 3. Some of the most relevant studies on follow-up

\begin{tabular}{lccc}
\hline Retrospective study & Patient & Intervention & Evaluation of DFS-OS or time of follow-up \\
\hline Flynn et al. (2010) [17] & 223 HNC stage III-IV & $\begin{array}{c}\text { Self-detection vs. } \\
\text { physician detected }\end{array}$ & $\begin{array}{c}\text { No evidence to suggest a significant improvement in DFS or OS in the } \\
\text { physician-detected versus patient-detected groups. Regional and distant } \\
\text { recurrences were only detected by physicians in one-fifth of cases and, } \\
\text { overall, patients self-detected their own recurrence in two-thirds of the } \\
\text { cases that experienced disease progression within the sample. }\end{array}$
\end{tabular}

$\begin{array}{lll}\text { Kissun et al. (2006) [48] } & \begin{array}{c}278 \text { Oral cavity } \\ \text { oropharynx } \\ \text { all stage }\end{array} & \text { Clinical+imaging } \\ \text { Boysen et al. (1992) [15] } & 661 \text { HNC stage III-IV } & \begin{array}{c}\text { Clinical control, } \\ \text { imaging) }\end{array}\end{array}$

$19 \%$ Recurrent disease. Recurrence occurred at a median time of 8 months after the initial operation and most (49/54) within 2 years. Suggested to review patients in the first three years.

The overall 'recurrence pick-up rate' and subsequent 'cure rate' was 1:36 and 1:113 consultations, respectively. Only 39\% of the recurrences were detected through physical examination. Follow-up consultations revealed $9.1 \%$ of second primaries. Follow-up is not indicated three years after completion of treatment and should only be routine for patients who still have a treatment option left.

\begin{tabular}{|c|c|c|c|}
\hline $\begin{array}{l}\text { Cooney and Poulsen } \\
\text { (1999) [19] }\end{array}$ & $302 \mathrm{HNC}$ all stage & $\begin{array}{l}\text { Clinical control, } \\
\text { imaging }^{\text {a) }}\end{array}$ & $\begin{array}{l}119 \text { Relapsed of which } 117 \text { died. Routine follow-up did not improve pts } \\
\text { survival. In patients with advanced HNSCC, routine follow-up is more } \\
\text { important for evaluation of treatment results and emotional support than of } \\
\text { benefit in improving patient survival. }\end{array}$ \\
\hline Ritoe et al. (2006) [49] & 113 HNC all stage & $\begin{array}{l}\text { Clinical control, } \\
\text { imaging }^{\text {a) }}\end{array}$ & $\begin{array}{l}64 \% \text { of recurrence in follow-up visit in symptomatic patients. Curative } \\
\text { therapy could only be offered to } 27.5 \% \text { of these patients. Only } 5 \% \text { of the } \\
\text { patients were disease free at the end of the study period. Many patients } \\
\text { with cancer recurrence needed interventions. }\end{array}$ \\
\hline $\begin{array}{l}\text { Lester and Wight (2009) } \\
\text { [13] }\end{array}$ & $676 \mathrm{HNC}$ all stage & $\begin{array}{l}\text { Clinical control, } \\
\text { imaging }^{\text {a) }}\end{array}$ & $\begin{array}{l}105 \text { Recurrences and } 20 \text { seconds primary cancers were recorded. Time to } \\
\text { a new cancer event was calculated in years. These were for larynx } 4.7 \\
\text { years, oropharynx } 2.7 \text { years, and hypopharynx } 2.3 \text { years. }\end{array}$ \\
\hline $\begin{array}{l}\text { De Visscher and Manni } \\
\text { (1994) [11] }\end{array}$ & $\begin{array}{l}428 \text { Larynx, pharynx, } \\
\text { and oral cavity all } \\
\text { stage }\end{array}$ & $\begin{array}{l}\text { Routine follow-up vs. } \\
\text { self-referral }\end{array}$ & $\begin{array}{l}\text { The detection rate for events during routine follow-up ( } 6,350 \text { appointments) } \\
\text { was one in } 34 \text {, and for self-referrals (54) it was one in } 2.7 \text {; the cure rates } \\
\text { were one in } 78 \text { and one in } 6.8 \text {, respectively. Routine follow-up is indispen- } \\
\text { sible. Site and stage of the index tumor played a part in the length of rou- } \\
\text { tine follow-up, in contrast to the differentiation grade or type of initial treat- } \\
\text { ment. Yearly chest roentgenograms were valuable only for laryngeal index } \\
\text { tumors. }\end{array}$ \\
\hline Spector et al. (2001) [50] & $2,550 \mathrm{HNC}$ & $\begin{array}{l}\text { Clinical control, } \\
\text { imaging }^{\text {a) }}\end{array}$ & $\begin{array}{l}\text { 12.4\% Delayed regional metastases; } 8.5 \% \text { distant metastases; } 8.9 \% \\
\text { second primary tumors } 5 \text {-year disease-specific survival } 41 \%, 6.4 \% \text {, and } \\
35 \% \text {, respectively. SPMs were not statistically related to the origin of the } \\
\text { primary tumor, tumor staging, or delayed regional and distant metastases } \\
(P=0.98) \text {. }\end{array}$ \\
\hline Schwartz et al. (1994) [29] & 115 HNC stage I-III & $\begin{array}{l}\text { Clinical control, } \\
\text { imaging }^{\text {a) }}\end{array}$ & $\begin{array}{l}\text { Eighty-six percent ( } 19 \text { of } 22 \text { ) of potentially salvageable locoregional failures } \\
\text { were discovered secondary to symptomatic complaint rather than by test } \\
\text { results. Disease failure, whether detected by symptom or testing, } \\
\text { predicted for poor survival ( } 22 \% \text { at } 24 \text { months after recurrence). Post-RT } \\
\text { surveillance for head and neck cancer is inconsistently pursued. A proven } \\
\text { correlation between intensive follow-up and improved patient survival is } \\
\text { lacking. }\end{array}$ \\
\hline O'Meara et al. (2003) [51] & $161 \mathrm{HNSCC}$ & $\begin{array}{l}\text { Routine follow-up } \\
\text { visits }\end{array}$ & $\begin{array}{l}\text { Physical examinations contributed to the diagnosis of } 24 \text { local recurrences } \\
\text { and four metachronous HNCs; surgical salvage occurred in } 18 \text { of the } \\
\text { recurrences, and definitive RT or surgery took place in three of the SPMs } \\
\text { physical examination and thyroid function testing remain valid parts of } \\
\text { routine follow-up for head and neck cancer patients; chest X-rays appear } \\
\text { less vital unless the patient's clinical situation warrants aggressive therapy } \\
\text { of a second primary lung cancer. }\end{array}$ \\
\hline Wong et al. (2003) [35] & 377 HNSCC & $\begin{array}{l}\text { Clinical control, } \\
\text { imaging }^{\text {a) }}\end{array}$ & $\begin{array}{l}\text { The surgical salvage rates of recurrence were } 29 \% \text { local, } 30 \% \text { tracheosto- } \\
\text { mal, } 56 \% \text { unilateral nodal recurrence of previously undissected neck, 32\% } \\
\text { of unilateral neck recurrence after prior neck dissection, and } 11 \% \text { lung } \\
\text { metastasis. The } 5 \text {-year tumor-free actuarial survival rates of those patients } \\
\text { who received surgical salvage was 35\% for local recurrence, 32\% for } \\
\text { unilateral nodal recurrence of the previously undissected neck, and } 18 \% \\
\text { for nodal recurrence of the previously dissected neck. }\end{array}$ \\
\hline
\end{tabular}

(Continued to the next page) 
Table 3. Continued

\begin{tabular}{|c|c|c|c|}
\hline Retrospective study & Patient & Intervention & Evaluation of DFS-OS or time of follow-up \\
\hline $\begin{array}{l}\text { Zatterstrom et al. (2014) } \\
\text { [52] }\end{array}$ & $\begin{array}{l}537 \text { Stage II or } \\
\text { IV HNSCC }\end{array}$ & Physical examination & $\begin{array}{l}\text { Self-reported symptoms led to diagnosis of the recurrence in } 78 \% \text { of the } \\
\text { cases. Only } 22 \% \text { of recurrences were detected through physical } \\
\text { examination of asymptomatic patients. There was no difference in DFS } \\
\text { in-between these two groups. }\end{array}$ \\
\hline $\begin{array}{l}\text { Rennemo et al. (2008) } \\
\text { [53] }\end{array}$ & $\begin{array}{l}\text { 2,063 Stage II or } \\
\text { IV HNSCC }\end{array}$ & $\begin{array}{l}\text { Clinical control, } \\
\text { imaginga) }\end{array}$ & $\begin{array}{l}\text { The mean annual rate of second primary tumors was 3.9\% through the first } \\
10 \text { years after diagnosis of the index tumor. Forty patients (11\%) were } \\
\text { treated for local or regional recurrence before having second primary } \\
\text { tumors. Patients ( } 17 \% \text { ) developed a second primary, mean time to } \\
\text { diagnosis of the second tumor being more than } 4 \text { years from the date of } \\
\text { the initial tumor. }\end{array}$ \\
\hline Agrawal et al. (2009) [18] & 105 & $\begin{array}{l}\text { Clinical control, } \\
\text { imaging }\end{array}$ & $\begin{array}{l}\text { Better survival was seen in patients with original prior early stage disease } \\
(P=0.0001) \text { and in patients with local-only site of disease recurrence } \\
(P=0.0001) \text {. The majority of patients ( } 85 \%) \text { diagnosed with recurrent HNC } \\
\text { had self-identified clinical symptoms. }\end{array}$ \\
\hline Ritoe et al. (2007) [12] & $\begin{array}{l}\text { Markov model, } \\
\text { a cohort simulation }\end{array}$ & $\begin{array}{l}\text { Follow-up vs. no } \\
\text { follow-up }\end{array}$ & $\begin{array}{l}\text { Abolishing the current follow-up schedule raised the disease-specific } \\
\text { mortality rate; the increase ranged from } 2.8 \% \text { to } 5.9 \% \text {. Variations of }+/-25 \% \\
\text { in the transition rates produced only a modest effect on life expectancy. }\end{array}$ \\
\hline Ferreira et al. (2015) [54] & 367 & $\begin{array}{l}\text { Clinical control, } \\
\text { imaging }\end{array}$ & $\begin{array}{l}\text { The } 2 \text {-year Kaplan-Meier locoregional recurrence incidence was } 10 \% \text {. } \\
\text { Tumor recurrences occurred in } 22 \text { patients in a mean time of } 16.5 \pm 9.4 \\
\text { months resulting in } 28 \text { recurrence volumes. }\end{array}$ \\
\hline Shah et al. (2015) [55] & 362 & $\begin{array}{l}\text { Standard follow-up vs. } \\
\text { PET stratified follow- } \\
\text { up }\end{array}$ & $\begin{array}{l}{ }^{18} \text { Fluorodeoxyglucose-PET/CT to stratify follow-up intensity after radical } \\
\text { radiotherapy for head and neck cancer reduces costs with no apparent } \\
\text { clinical detriment. }\end{array}$ \\
\hline Kao et al. (2009) [22] & 240 & $\begin{array}{l}\text { Clinical examination, } \\
\text { PET/CT, and } \\
\text { correlative imaging } \\
\text { (median follow-up, } \\
21 \text { mo) }\end{array}$ & $\begin{array}{l}\text { Although post-therapy follow-up using PET/CT is reportedly associated with } \\
\text { a high false-positive rate in the irradiated head and neck, PET/CT appears } \\
\text { to be a highly sensitive technique for the detection of recurrent disease. }\end{array}$ \\
\hline Trosman et al. (2015) [31] & 291 & $\begin{array}{l}\text { 28/252 HPV positive, } \\
\text { 9/39 HPV negative }\end{array}$ & $\begin{array}{l}\text { 3-Year projected distant control rate } 88 \% \text { vs. } 74 \% ; P=0.01 \text { in HPV positive } \\
\text { vs. HPV negative. } \\
\text { Median time to develop distant metastases } 16.4 \text { vs. } 7.2 \text { months in HPV } \\
\text { positive vs. HPV negative. } \\
\text { No. of metastatic sites involved } 2.04 \text { vs. } 1.33 \text { sites; } P=0.09 \text { in HPV positive } \\
\text { vs. HPV negative. }\end{array}$ \\
\hline Schwartz et al. (2003) [14] & 851 & $\begin{array}{l}\text { Clinical control, } \\
\text { imaging }^{\text {a) }}\end{array}$ & $\begin{array}{l}19 \% \text { Second HNSCC ( } 41 \% \text { synchronous and } 59 \% \text { metachronous). The } \\
\text { probability of developing a SPMs at } 5 \text { years }=22 \% \text {. } \\
\text { OS rate }=20 \% \text { for a second HNSCC, } 3 \% \text { for a second esophageal cancer, } \\
\text { and } 2 \% \text { for a second lung cancer. OS rate }=20 \% \text { for non-smokers vs. } 5 \% \\
\text { for smokers and } 27 \% \text { for non-drinkers vs. } 6 \% \text { for drinkers. }\end{array}$ \\
\hline Pagh et al. (2015) [56] & 197 & $\begin{array}{l}\text { Clinical control, } \\
\text { imaginga) }^{\text {a }}\end{array}$ & $\begin{array}{l}\text { 1,408 Follow-up visits. } 141 \text { patients completed follow-up. Only } 15 \text { of the } 141 \\
\text { patients had no tumor problems or morbidity issues raised at any follow- } \\
\text { up visit. Suspicion of recurrent disease was observed at } 207 \text { of the } 1,408 \\
\text { follow-up visits ( } 82 \text { within three and one half years after end of treatment). } \\
\text { Late treatment-related morbidity was recorded in } 82 \% \text { patients. }\end{array}$ \\
\hline
\end{tabular}

DFS, disease free survival; OS, overall survival; HNC, head and neck carcinoma; HNSCC, head and neck squamous cell carcinoma; SPMs, second primary malignancies; RT, radiotherapy; PET/CT, positron emission tomography/computed tomography; HPV, human papillomavirus. a)CT scans, chest radiographs, and fine needle aspiration cytology from clinically suspicious nodes.

of cancer. Patients not fit for curative intent of recurrence, may receive less intensive imaging (only when symptomatic). We suggest a multidisciplinary follow-up visit, and a specific algorithm for each sub-site (Fig. 1).

\section{TREATMENT SIDE EFFECTS EVALUATIONS}

Treatment-related side effects include acute events and long- term treatment effects (begin during treatment and continue beyond the end) and late effects (manifest months to years after the end of the treatment). Detecting/treating complications means to search for hypothyroidism, carotid stenosis, dysphagia, depression, dental status, and speech-hearing.

Xerostomia, dysphagia, weight loss, and pain are common long-term effects, while fibrosis, neck rigidity, and lymphoedema are late effects. Unfortunately only in the last decade atten- 


\section{LARING}
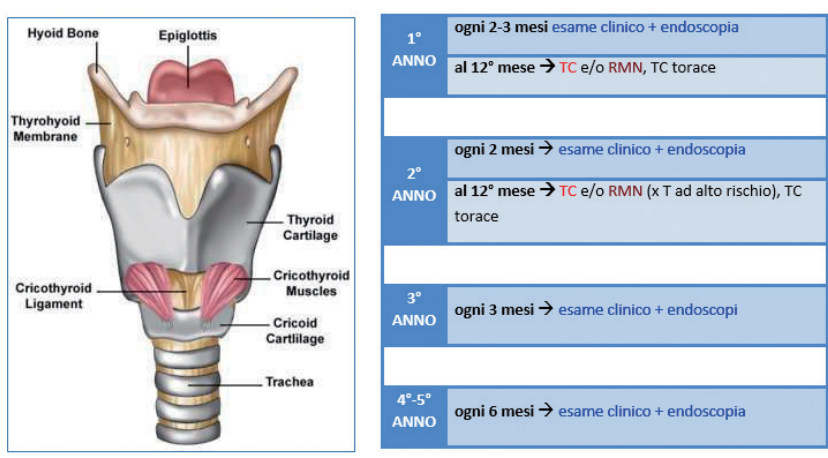

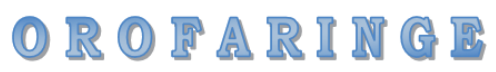

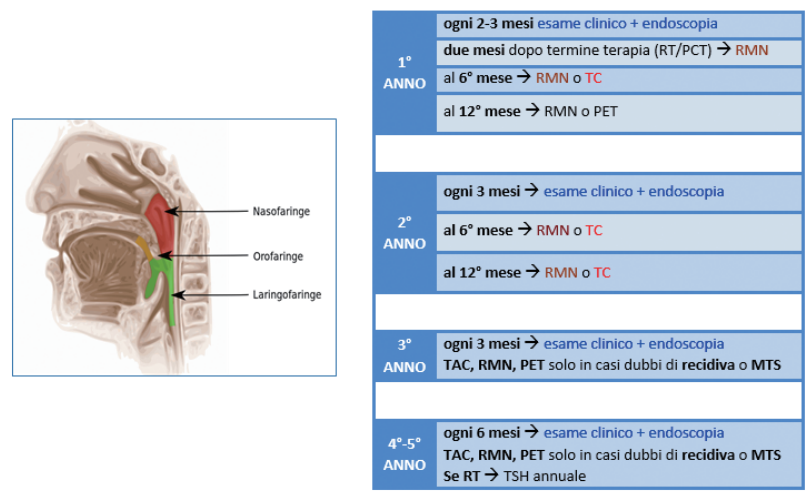

IPOPARIDG
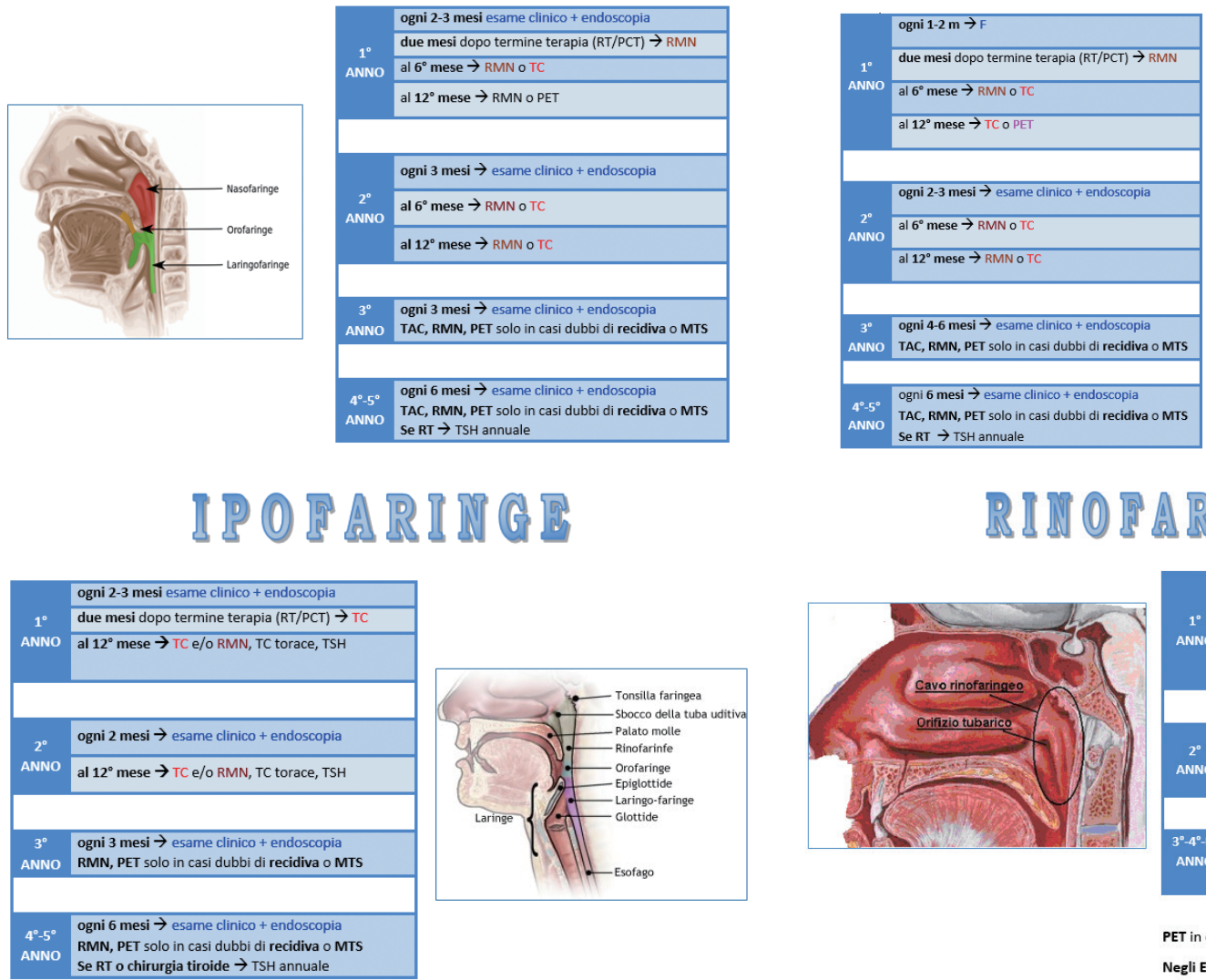

\section{RIMOPARIAG}

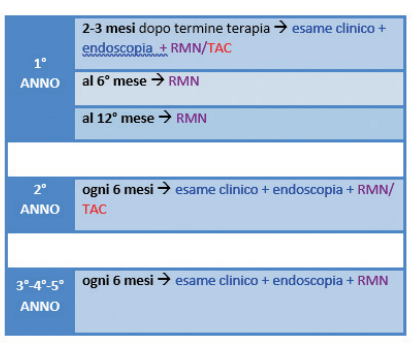

PET in casi dubbi di recidiva o MTS

Se RT $\rightarrow$ TSH annuale
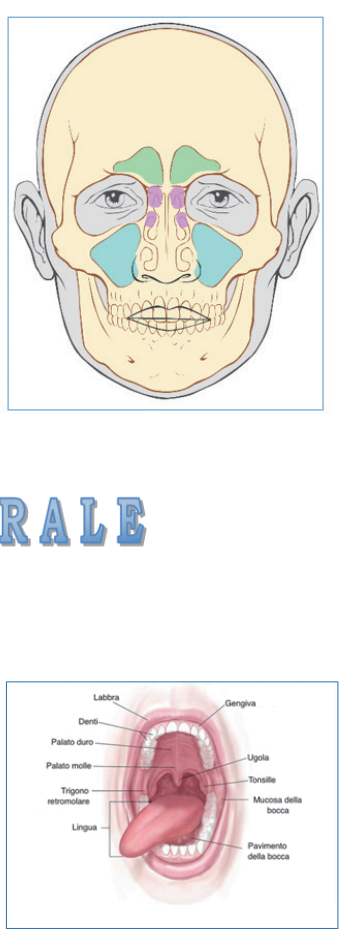

RAL

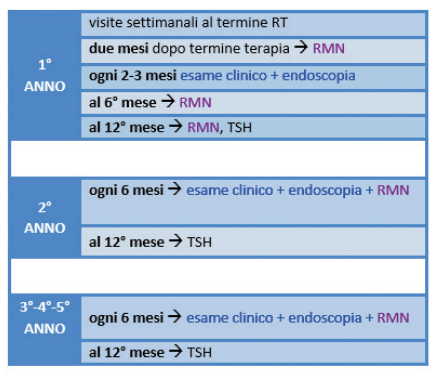

PET in casi dubbi di recidiva o MTS

Negli EBV +, controllo EBV-DNA $2^{\circ}-6^{\circ}-24^{\circ}-36^{\circ}$ mese

Fig. 1. Follow-up algorithms. For each subsite TSH annually, smoking and alcohol cessation suggested to all patients. Clinical examination according to National Comprehensive Cancer Network should include ear, nose and throat evaluation, pain/xerostomia/depression management, nutritional support, dental care, and speech and swallowing therapy. All CT scan and MRI are considered with contrast. Patients with PS $>2$, or with comorbidity that contraindicate treatment are not followed up for the disease. TNM, tumor-node-metastasis; CT, computed tomography; MRI, magnetic resonance imaging; PET, positron emission tomography; PS, performance status; TSH, thyroid stimulating hormone; CRT, chemoradiation; M, months; NFE, nasal/pharyngo/laryngeal fiber optic examination; ACF, anterior cranial fossa; MCF, medial cranial fos-

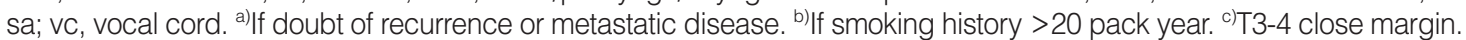

tion has been made on quality of life and function impairment. Recently a consensus conference on late effect on HNC provides recommendation on this topic, before of this conference only few symptoms had been evaluated. Actually nutritional status should be evaluated at each visit. Vocal assessment and swallowing function should be evaluated by a swallowing expert (according with American Association of speech and language pathologist). Tumor itself causes swallowing impairment and 
CRT does not resolve it but causes further deterioration [64]. Swallowing exercises should be recommended. Dental status and oral health should be assessed during follow-up visits.

Thyroid function-serum thyroid stimulating hormone (TSH) — should be tested at each visit because approximately one half of HNCPs who receive at least 44 Gy will experience hypothyroidism [65]. The NCCN proposes TSH evaluation every 6-12 months.

Moreover recent data suggest reflecting on non-cancer related deaths to avoid to treat tumor but to cause cardio-cerebral-vascular-respiratory health events.

Forastiere et al. [66] reported a worse survival for patients treated with CRT in the long-term analysis of Radiation Therapy Oncology Group 91-11. Rye et al. [67] reported at a long follow-up an increase of non-cancer event (18\% at 60 months).

\section{cosTs}

While in other solid cancer (breast, colon, and lung cancer) a more intense follow-up protocol did not offer a survival advantage with unjustified costs, in HNC follow-up cost have not been deeply studied. Despite HNC are extremely expensive to treat, have a high morbidity, and of those individuals that survive only $48 \%$ return to work, researches on the direct and indirect cost burden are limited. In 2001 van Agthoven et al. [68] reported the costs of 10-year-follow-up (euro 423 after discounting and correction for survival) calculating retrospectively on patients treated between 1994 and 1996 in two major Dutch university hospitals. In total, average costs per new patient were euro 31,829 , which covered discounted costs of treating the primary tumor, costs of treating recurrent tumors in $40 \%$ of all patients, and the costs of 10 years of follow-up. Costs of improving the quality of care were estimated to be (euro) 1,598 per new patient [68].

Lang et al. [69] confirmed these data analysing the impaired effect of CRT versus RT alone. In their study on 201 patients they described the mean per-patient costs associated with treatment-related complications founding a difference of approximately $\$ 10,000$ among patients who received CRT and RT alone $(P<0.001)$. These costs represented $17 \%$ of the total costs during follow-up for patients who received CRT and $11 \%$ of costs for those who received RT. The most expensive complications were dehydration and/or electrolyte imbalance and oral complications [68].

\section{DISCUSSION}

In the era of 'cancer survivorship' HNC follow-up has several goals including detections of recurrence and second primary tumors and evaluation/rehabilitation of acute and chronic treat- ment-related side effects. Physical clinical examination includes vocal, breathing, and swallowing assessment. Although technological innovation guarantee higher sensibility and specificity of imaging, no data confirm their role in improving outcome out of symptomatic patients. Therefore to allow a resource optimization reimaging is not routinely recommended in all asymptomatic HNCPs.

We suggest a different behaviour on the basis of patients' and tumors' characteristics (treatment options available for the specific case, performance status, age, and prognostic factors). Increasing the curability rate not decreasing the detection rate of asymptomatic recurrence should be the goal for each HNC multidisciplinary team. Therefore candidate to salvage surgery may deserve an intensive follow-up. In this setting not only treatment but also follow-up should be performed by an experienced team (with knowledge on supportive care). Research of SPMs might be intensified in HPV positive tumors, in elderly patients, in hypopharyngeal cancer patients, or in heavy drinkers. The possibility of follow-up de-intensification in HPV positive tumors is undefined, while several authors reported a better outcome and a lower risk of recurrence than HPV negative ones [59], other studies evidenced a higher risk of distant metastatization [3137,57-59].

In our opinion the multidisciplinary follow-up approach after CRT should include medical and radiation oncologists' evaluation of outcomes and toxicities, evaluation of tumor and metastasis by ENT, consultation with dentists, dieticians, swallowing experts, and radiologists on demand. (1) A physical head and neck exam (including mirror and fiber-optic examination) is advisable every 3 months for the first year; every 4 months for the next 2-3; every 6 months for the year 4-5; and annually thereafter. (2) Post-treatment baseline imaging of head and neck at 3 months from treatment's end (magnetic resonance imaging, CT, or if doubt of residue disease PET after 10-12 weeks) then reimaging annually (first two years) or if it is indicated, based on signs and symptoms. We suggest chest $\mathrm{CT}$ also for non-smokers (LA-HNCPs) to assess metastasis and second tumors in the first 3 years; heavy smokers ( $>20$ pack years) were followed with annual low dose CT for a longer period ( $>3$ years). (3) Side effects and clinical symptoms evaluation are performed in each visit (including speech and swallowing evaluation to plan rehabilitation program). (4) Thyroid stimulating hormone is checked every 6 months (according to literature) [70].

\section{CONCLUSIONS}

A correct follow-up in HNC is essential to avoid under- or overtreatment, and it ensure the opportunity both to improve the quality of life (by managing late side effects) and to increase the outcome (by curative early diagnosis). Timing of medical visits and instrumental exams differ depending on the stage of disease 
at diagnosis, type of treatment received, the site of the tumor, and variables related to the patient (e.g., age and comorbidity).

A personalized approach in a qualified multidisciplinary team is strongly recommended. In the future a tailored surveillance plan should be offered to all HNCPs (evaluating curability rates and molecular markers). Addition of more sensitive and specific techniques of detection could also improve outcome without impact negatively on the costs.

\section{CONFLICT OF INTEREST}

No potential conflict of interest relevant to this article was reported.

\section{REFERENCES}

1. Gregoire V, Lefebvre JL, Licitra L, Felip E; EHNS-ESMO-ESTRO Guidelines Working Group. Squamous cell carcinoma of the head and neck: EHNS-ESMO-ESTRO Clinical Practice Guidelines for diagnosis, treatment and follow-up. Ann Oncol. 2010 May;21 Suppl 5:v184-6.

2. Sturgis EM, Miller RH. Second primary malignancies in the head and neck cancer patient. Ann Otol Rhinol Laryngol. 1995 Dec; 104(12):946-54.

3. Roman BR, Goldenberg D, Givi B; Education Committee of American Head and Neck Society (AHNS). AHNS Series-Do you know your guidelines?: guideline recommended follow-up and surveillance of head and neck cancer survivors. Head Neck. 2016 Feb;38(2):168-74.

4. Digonnet A, Hamoir M, Andry G, Vander Poorten V, Haigentz M Jr, Langendijk JA, et al. Follow-up strategies in head and neck cancer other than upper aerodigestive tract squamous cell carcinoma. Eur Arch Otorhinolaryngol. 2013 Jul;270(7):1981-9.

5. Hermans R, Pameijer FA, Mancuso AA, Parsons JT, Mendenhall WM. Laryngeal or hypopharyngeal squamous cell carcinoma: can follow-up CT after definitive radiation therapy be used to detect local failure earlier than clinical examination alone? Radiology. 2000 Mar;214(3):683-7.

6. Patel SN, Cohen MA, Givi B, Dixon BJ, Gilbert RW, Gullane PJ, et al. Salvage surgery for locally recurrent oropharyngeal cancer. Head Neck. Head Neck. 2016 Apr;38 Suppl 1:E658-64.

7. Janot F, de Raucourt D, Benhamou E, Ferron C, Dolivet G, Bensadoun RJ, et al. Randomized trial of postoperative reirradiation combined with chemotherapy after salvage surgery compared with salvage surgery alone in head and neck carcinoma. J Clin Oncol. 2008 Dec;26(34):5518-23.

8. Kramer NM, Horwitz EM, Cheng J, Ridge JA, Feigenberg SJ, Cohen $\mathrm{RB}$, et al. Toxicity and outcome analysis of patients with recurrent head and neck cancer treated with hyperfractionated split-course reirradiation and concurrent cisplatin and paclitaxel chemotherapy from two prospective phase I and II studies. Head Neck. 2005 May; 27(5):406-14.

9. Duprez F, Berwouts D, Madani I, Bonte K, Boterberg T, De Gersem $\mathrm{W}$, et al. High-dose reirradiation with intensity-modulated radiotherapy for recurrent head-and-neck cancer: disease control, survival and toxicity. Radiother Oncol. 2014 Jun;111(3):388-92.

10. Kakria A, Rawat S, Bhutani R, Gupta G, Devnani B, Wahi IK, et al. Retrospective analysis of treatment outcomes following reirradiation in locoregionally recurrent head and neck cancer patients: a single institutional study. Asia Pac J Clin Oncol. 2015 Jun;11(2):129-34.

11. De Visscher AV, Manni JJ. Routine long-term follow-up in patients treated with curative intent for squamous cell carcinoma of the larynx, pharynx, and oral cavity: does it make sense? Arch Otolaryngol Head Neck Surg. 1994 Sep;120(9):934-9.

12. Ritoe SC, de Vegt F, Scheike IM, Krabbe PF, Kaanders JH, van den Hoogen FJ, et al. Effect of routine follow-up after treatment for laryngeal cancer on life expectancy and mortality: results of a Markov model analysis. Cancer. 2007 Jan;109(2):239-47.

13. Lester SE, Wight RG. 'When will I see you again?': using local recurrence data to develop a regimen for routine surveillance in posttreatment head and neck cancer patients. Clin Otolaryngol. 2009 Dec;34(6):546-51.

14. Schwartz DL, Barker J Jr, Chansky K, Yueh B, Raminfar L, Drago P, et al. Postradiotherapy surveillance practice for head and neck squamous cell carcinoma: too much for too little? Head Neck. 2003 Dec; 25(12):990-9.

15. Boysen M, Lovdal O, Tausjo J, Winther F. The value of follow-up in patients treated for squamous cell carcinoma of the head and neck. Eur J Cancer. 1992;28(2-3):426-30.

16. Francis DO, Yueh B, Weymuller EA Jr, Merati AL. Impact of surveillance on survival after laryngeal cancer in the medicare population. Laryngoscope. 2009 Dec;119(12):2337-44.

17. Flynn CJ, Khaouam N, Gardner S, Higgins K, Enepekides D, Balogh $\mathrm{J}$, et al. The value of periodic follow-up in the detection of recurrences after radical treatment in locally advanced head and neck cancer. Clin Oncol (R Coll Radiol). 2010 Dec;22(10):868-73.

18. Agrawal A, HammondTH, Young GS, Avon AL, Ozer E, Schuller DE. Factors affecting long-term survival in patients with recurrent head and neck cancer may help define the role of post-treatment surveillance. Laryngoscope. 2009 Nov;119(11):2135-40.

19. CooneyTR, Poulsen MG. Is routine follow-up useful after combinedmodality therapy for advanced head and neck cancer? Arch Otolaryngol Head Neck Surg. 1999 Apr;125(4):379-82.

20. Hsu YB, Chu PY, Liu JC, Lan MC, Chang SY,Tsai TL, et al. Role of chest computed tomography in head and neck cancer. Arch Otolaryngol Head Neck Surg. 2008 Oct;134(10):1050-4.

21. Wang SJ. Surveillance radiologic imaging after treatment of oropharyngeal cancer: a review. World J Surg Oncol. 2015 Mar;13:94.

22. Kao J, Vu HL, Genden EM, Mocherla B, Park EE, Packer S, et al. The diagnostic and prognostic utility of positron emission tomography/ computed tomography-based follow-up after radiotherapy for head and neck cancer. Cancer. 2009 Oct;115(19):4586-94.

23. Manikantan K, Dwivedi RC, Sayed SI, Pathak KA, Kazi R. Current concepts of surveillance and its significance in head and neck cancer. Ann R Coll Surg Engl. 2011 Nov;93(8):576-82.

24. Krabbe CA, Pruim J, Dijkstra PU, Balink H, van der Laan BF, de Visscher JG, et al. 18F-FDG PET as a routine posttreatment surveillance tool in oral and oropharyngeal squamous cell carcinoma: a prospective study. J Nucl Med. 2009 Dec;50(12):1940-7.

25. Ho AS, Tsao GJ, Chen FW, Shen T, Kaplan MJ, Colevas AD, et al. Impact of positron emission tomography/computed tomography surveillance at 12 and 24 months for detecting head and neck cancer recurrence. Cancer. 2013 Apr;119(7):1349-56.

26. Dunsky KA, Wehrmann DJ, Osman MM, Thornberry BM, Varvares MA. PET-CT and the detection of the asymptomatic recurrence or second primary lesions in the treated head and neck cancer patient. Laryngoscope. 2013 Sep;123(9):2161-4.

27. Lee DH, Roh JL, Baek S, Jung JH, Choi SH, Nam SY, et al. Second cancer incidence, risk factor, and specific mortality in head and neck squamous cell carcinoma. Otolaryngol Head Neck Surg. 2013 Oct; 149(4):579-86.

28. Jegu J, Binder-Foucard F, Borel C, Velten M. Trends over three de- 
cades of the risk of second primary cancer among patients with head and neck cancer. Oral Oncol. 2013 Jan;49(1):9-14.

29. Schwartz LH, Ozsahin M, Zhang GN, Touboul E, De Vataire F, Andolenko P, et al. Synchronous and metachronous head and neck carcinomas. Cancer. 1994 Oct;74(7):1933-8.

30. Do KA, Johnson MM, Doherty DA, Lee JJ, Wu XF, Dong Q, et al. Second primary tumors in patients with upper aerodigestive tract cancers: joint effects of smoking and alcohol (United States). Cancer Causes Control. 2003 Mar;14(2):131-8.

31. Trosman SJ, Koyfman SA, Ward MC, Al-Khudari S, Nwizu T, Greskovich JF, et al. Effect of human papillomavirus on patterns of distant metastatic failure in oropharyngeal squamous cell carcinoma treated with chemoradiotherapy. JAMA Otolaryngol Head Neck Surg. 2015 May;141(5):457-62.

32. Kwon M, Roh JL, Song J, Lee SW, Kim SB, Choi SH, et al. Effect of metformin on progression of head and neck cancers, occurrence of second primary cancers, and cause-specific survival. Oncologist. 2015 May;20(5):546-53.

33. Jain KS, Sikora AG, Baxi SS, Morris LG. Synchronous cancers in patients with head and neck cancer: risks in the era of human papillomavirus-associated oropharyngeal cancer. Cancer. 2013 May;119 (10):1832-7.

34. Gleich LL, Ryzenman J, Gluckman JL, Wilson KM, Barrett WL, Redmond KP. Recurrent advanced (T3 or T4) head and neck squamous cell carcinoma: is salvage possible? Arch Otolaryngol Head Neck Surg. 2004 Jan;130(1):35-8.

35. Wong LY, Wei WI, Lam LK, Yuen AP. Salvage of recurrent head and neck squamous cell carcinoma after primary curative surgery. Head Neck. 2003 Nov;25(11):953-9.

36. Paniello RC, Virgo KS, Johnson MH, Clemente MF, Johnson FE. Practice patterns and clinical guidelines for posttreatment follow-up of head and neck cancers: a comparison of 2 professional societies. Arch Otolaryngol Head Neck Surg. 1999 Mar;125(3):309-13.

37. National Comprehensive Cancer Network. NCCN guidelines: NCCN guidelines for treatment of cancer by site [Internet]. Fort Washington (PA): National Comprehensive Cancer Network; c2015 [cited 2016 May 8]. Available from: http://www.nccn.org/professionals/physician_gls/f_guidelines.asp\#site.

38. Hwang HS, Perez DA, Orloff LA. Comparison of positron emission tomography/computed tomography imaging and ultrasound in staging and surveillance of head and neck and thyroid cancer. Laryngoscope. 2009 Oct;119(10):1958-65.

39. Wierzbicka M, Popko M, Piskadlo K, Czepczynski R, Stankowska A, Pietka T, et al. Comparison of positron emission tomography/computed tomography imaging and ultrasound in surveillance of head and neck cancer: the 3-year experience of the ENT Department in Poznan. Rep Pract Oncol Radiother. 2011 Sep 29;16(5):184-8.

40. Kangelaris GT, Yom SS, Huang K, Wang SJ. Limited utility of routine surveillance MRI following chemoradiation for advanced-stage oropharynx carcinoma. Int J Otolaryngol. 2010;2010:904297.

41. Vandecaveye V, De Keyzer F, Nuyts S, Deraedt K, Dirix P, Hamaekers $\mathrm{P}$, et al. Detection of head and neck squamous cell carcinoma with diffusion weighted MRI after (chemo)radiotherapy: correlation between radiologic and histopathologic findings. Int J Radiat Oncol Biol Phys. 2007 Mar 15;67(4):960-71.

42. American Head \& Neck Society. Education [Internet]. Los Angeles (CA): American Head \& Neck Society; 2016 [cited 2016 May 8]. Available from: http://www.ahns.info/resources/education/.

43. British Association of Otorhinolaryngology. Head and neck cancer: multidisciplinary management guidelines [Internet]. London: British Association of Otorhinolaryngology; 2011 [cited 2016 May 8]. Available from: http://bahno.org.uk/wp-content/uploads/2014/03/ Multidisciplinary-Management-Guidelines-for-Head-and-NeckCancer.pdf.
44. ORL France. Recommandations SFORL [Internet]. Paris: ORL France; [cited 2016 May 8]. Available from: http://www.orlfrance. org/article.php?id=20.

45. Nederlandse Werkgroep Hoofd Hals Tumoren. Medisch Maatschappelijk Werk [Internet]. Nederlandse Werkgroep Hoofd Hals Tumoren; [cited 2016 May 8]. Available from: http://www.nwhht.nl/paramedische-werkgroep/medisch-maatschappelijk-werk.

46. Associazione Italiana di Radioterapia Oncologica (AIRO). Linee guida AIRO [Internet]. Roma: Associazione Italiana di Radioterapia Oncologica; [cited 2016 May 8]. Available from: http://www.radioterapiaitalia.it/cont_169.phtml.

47. Associazione Italiana di Oncologia Medica (AIOM). Linee guida AIOM [Internet]. Milano: Associazione Italiana di Oncologia Medica; [cited 2016 May 8]. Available from: http://www.aiom.it/professionisti/documenti-scientifici/linee-guida/1\%2C413\%2C1\%2C\#TopList.

48. Kissun D, Magennis P, Lowe D, Brown JS, Vaughan ED, Rogers SN. Timing and presentation of recurrent oral and oropharyngeal squamous cell carcinoma and awareness in the outpatient clinic. Br J Oral Maxillofac Surg. 2006 Oct;44(5):371-6.

49. Ritoe SC, Bergman H, Krabbe PF, Kaanders JH, van den Hoogen FJ, VerbeekAL, et al. Cancer recurrence after total laryngectomy: treatment options, survival, and complications. Head Neck. 2006 May; 28(5):383-8.

50. Spector JG, Sessions DG, Haughey BH, Chao KS, Simpson J, El Mofty S, et al. Delayed regional metastases, distant metastases, and second primary malignancies in squamous cell carcinomas of the larynx and hypopharynx. Laryngoscope. 2001 Jun;111(6):1079-87.

51. O'Meara WP, Thiringer JK, Johnstone PA. Follow-up of head and neck cancer patients post-radiotherapy. Radiother Oncol. 2003 Mar; 66(3):323-6.

52. Zatterstrom U, Boysen M, Evensen JF. Significance of self-reported symptoms as part of follow-up routines in patients treated for oral squamous cell carcinoma. Anticancer Res. 2014 Nov;34(11):6593-9.

53. Rennemo E, Zatterstrom U, Boysen M. Impact of second primary tumors on survival in head and neck cancer: an analysis of 2,063 cases. Laryngoscope. 2008 Aug;118(8):1350-6.

54. Ferreira BC, Marques RV, Khouri L, SantosT, Sa-Couto P, do Carmo Lopes M. Assessment and topographic characterization of locoregional recurrences in head and neck tumours. Radiat Oncol. 2015 Feb;10:41.

55. Shah K,Te Marvelde L, Collins M, DeAbreu Lourenco R, D’Costa I, Coleman A, et al. Safety and cost analysis of an (18)FDG-PET-CT response based follow-up strategy for head and neck cancers treated with primary radiation or chemoradiation. Oral Oncol. 2015 May; 51(5):529-35.

56. Pagh A, Grau C, Overgaard J. A longitudinal study of follow-up activities after curative treatment for head and neck cancer. Acta Oncol. 2015 May;54(5):813-9.

57. Joshi A, Calman F, O'Connell M, Jeannon JP, Pracy P, Simo R. Current trends in the follow-up of head and neck cancer patients in the UK. Clin Oncol (R Coll Radiol). 2010 Mar;22(2):114-8.

58. Merlano MC, Monteverde M, Colantonio I, Denaro N, Lo Nigro C, Natoli G, et al. Impact of age on acute toxicity induced by bio- or chemo-radiotherapy in patients with head and neck cancer. Oral Oncol. 2012 Oct;48(10):1051-7.

59. Ang KK, Harris J, Wheeler R, Weber R, Rosenthal DI, Nguyen-Tan $\mathrm{PF}$, et al. Human papillomavirus and survival of patients with oropharyngeal cancer. N Engl J Med. 2010 Jul;363(1):24-35.

60. O'Sullivan B, Huang SH, Siu LL, Waldron J, Zhao H, Perez-Ordonez $B$, et al. Deintensification candidate subgroups in human papillomavirus-related oropharyngeal cancer according to minimal risk of distant metastasis. J Clin Oncol. 2013 Feb;31(5):543-50.

61. Bledsoe TJ, Noble AR, Hunter GK, Rybicki LA, Hoschar A, Chute DJ, et al. Oropharyngeal squamous cell carcinoma with known hu- 
man papillomavirus status treated with definitive chemoradiotherapy: patterns of failure and toxicity outcomes. Radiat Oncol. 2013 Jul;8:174.

62. Subramaniam RM, Alluri KC, Tahari AK, Aygun N, Quon H. PET/ $\mathrm{CT}$ imaging and human papilloma virus-positive oropharyngeal squamous cell cancer: evolving clinical imaging paradigm. J Nucl Med. 2014 Mar;55(3):431-8.

63. Tiwana MS, Wu J, Hay J,Wong F, Cheung W, Olson RA. 25 year survival outcomes for squamous cell carcinomas of the head and neck: population-based outcomes from a Canadian province. Oral Oncol. 2014 Jul;50(7):651-6.

64. Russi EG, Corvo R, Merlotti A, Alterio D, Franco P, Pergolizzi S, et al. Swallowing dysfunction in head and neck cancer patients treated by radiotherapy: review and recommendations of the supportive task group of the Italian Association of Radiation Oncology. Cancer Treat Rev. 2012 Dec;38(8):1033-49.

65. Bakhshandeh M, Hashemi B, Mahdavi SR, Nikoofar A, Vasheghani M, Kazemnejad A. Normal tissue complication probability modeling of radiation-induced hypothyroidism after head-and-neck radiation therapy. Int J Radiat Oncol Biol Phys. 2013 Feb;85(2):514-21.
66. Forastiere AA, Zhang Q, Weber RS, Maor MH, Goepfert H, Pajak TF, et al. Long-term results of RTOG 91-11: a comparison of three nonsurgical treatment strategies to preserve the larynx in patients with locally advanced larynx cancer. J Clin Oncol. 2013 Mar;31(7):84552.

67. Ryu CH, Roh JL, Kim SB, Lee SW, Choi SH, Nam SY, et al. Risk factors for non-cancer health events in patients with head and neck squamous cell carcinoma. Ann Oncol. 2013 Apr;24(4):1049-54.

68. van Agthoven M, van Ineveld BM, de Boer MF, Leemans CR, Knegt PP, Snow GB, et al. The costs of head and neck oncology: primary tumours, recurrent tumours and long-term follow-up. Eur J Cancer. 2001 Nov;37(17):2204-11.

69. Lang K, Sussman M, Friedman M, Su J, Kan HJ, Mauro D, et al. Incidence and costs of treatment-related complications among patients with advanced squamous cell carcinoma of the head and neck. Arch Otolaryngol Head Neck Surg. 2009 Jun;135(6):582-8.

70. Vogelius IR, Bentzen SM, Maraldo MV, Petersen PM, Specht L. Risk factors for radiation-induced hypothyroidism: a literature-based meta-analysis. Cancer. 2011 Dec;117(23):5250-60. 